\title{
MONEY ATTITUDE OF UKRAINIAN YOUNG PEOPLE: SOCIO-DEMOGRAPHIC ASPECT
}

\author{
MARIANNA SIMKIV \\ simkiv.m@gmail.com \\ Ivan Franko Lviv National University, \\ Ukraine
}

\begin{abstract}
The article provides the results of research on how social and demographic peculiarities influence money attitudes of Ukrainian youth. It reveals dependency on money attitudes on such characteristics as gender, age, education, place of residence, place of employment, employment position and income level.
\end{abstract}

Key words: money attitude, age, gender, education, income.

Traditionally money is studied from the point of view of its economic essence. First of all, money performs economic functions such as a medium of exchange, payment and accumulation of wealth and is a universal measure of the cost of goods and services. However, scientific approaches to researching the problem of money have already gone beyond purely economic issues as money has also acquired social and psychological features. Certainly it is reflected on many fields of social life in general and the individual's life in particular. Penetrating into all spheres of the life of society money makes changes and undoubtedly influences the development of economy, politics, culture, etc. Personality also falls under its influence as money becomes an instrument to satisfy one's own needs and achieve goals. Moreover, according to Iryna Zubiashvili (Iryna Zubiashvili, 2009, 16 p.), without knowledge about money and undeveloped skills as to how to use it, it is difficult for a person to fully become part of the system of social interaction. Therefore, attitude to money has become one of the factors of personality socialization.

A lot of researchers from Western Europe and North America focus their attention on these issues (Adrian Furnham \& Michael Argyle, 1998, p. 332, Tomas Li-Ping Tang \& Pamela R. Gilbert, 1995, p. 327-332, Paul F. Wernimont \& Susan Fitzpatrick, 1972, p. 218-226, etc.). Ukrainian researchers-psychologists also show interest in the problem of attitude to money (Iryna Zubiashvili, 2009, 16 p., Valentyna Moskalenko, 2004, p. 3-21, Viktoriya Mialenko, 2008, p. 20, etc.). Researches of a person's money attitude are topical due to the fact that Ukrainian society is undergoing social and economic changes which inevitably affect economic consciousness of people, and youth in particular.

Money attitudes of a personality are formed in the process of growing personal experience of dealing with money matters under the conditions of interpersonal interaction. A number of studies prove that formation of money attitudes is affected by psychological peculiarities of a person (level of self-conception, control lo- 
calization, job satisfaction, etc.) as well as social and demographic characteristics, namely: age, gender, education, level of income, residential place (Adrian Furnham , 1984, p. 501-509, Tomas Li-Ping Tang \& Pamela R. Gilbert, 1995, p. 327-332, Paul F. Wernimont \& Susan Fitzpatrick, 1972, p. 218-226, etc.).

The findings of the research on money attitudes and demographic peculiarities of a person conducted by Paul F. Wernimont and Susan Fitzpatrick (Paul F. Wernimont \& Susan Fitzpatrick, 1972, p. 218-226) indicate that men attach more importance to money than women. Adrian Furnham (Adrian Furnham , 1984, p. 501-509) in his research has found out that women are more often obsessed with money. They are more conservative about financial issues and tend to think that they are worse at controlling their own financial condition than men. The findings of Michael Lynn's research (Adrian Furnham \& Michael Argyle, 1998, p. 332) show that for men money is more valuable. Prince (1991) has revealed that women more often think about financial security and are less confident while making financial agreements.

Such researchers as Melvin Prince (Melvin Prince, 1991, p. 284-291), Tomas Li-Ping Tang \& Pamela R. Gilbert(Tomas Li-Ping Tang \& Pamela R. Gilbert, 1995, p. 327-332), Vivien K. G. Lim \& Thompson S. H. Teo (Vivien K. G. Lim \& Thompson S. H. Teo, 1997, p. 369-386) have investigated that women more often use money as a tool to influence other people, i.e. to get more power and demonstrate one's own prestige. According to the results of Tomas Li-Ping Tang's research (Tomas Li-Ping Tang, 1996, p. 127-144), women more often plan their budgets than men. Similar results were obtained by Kent T. Yamauchi \& Donald I. Templer (Kent T. Yamauchi \& Donald I. Templer , 1982, p. 522-528) while researching attitude to money of representatives of different social groups. They have found out that there are gender differences in planning and saving money for the future and also that women more often tend to use money as a means to get power.

Besides gender differences, there are also age differences in a person's attitude to money. It is confirmed by the results of numerous studies in this field of scientific interest. Adrian Furnham (Adrian Furnham , 1984, p. 501-509) has indicated that young people are more inclined to use money as a means to influence other people, are less concerned about financial security and financial future as compared to older people. Tendency of older people to think about their financial security in the future is proved by Alice Hanley \& Mari S. Wilhelm (Alice Hanley \& Mari S. Wilhelm, 1992, p. 5-18). Tomas Li-Ping Tang \& Pamela R. Gilbert (Tomas Li-Ping Tang \& Pamela R. Gilbert, 1995, p. 327-332) state that older people are more careful about planning their expenses and consider money to be a symbol of their own success.

Interrelation of money attitudes with the level of income is confirmed by the findings of many studies. Thus, Paul F. Wernimont and Susan Fitzpatrick (Paul F. Wernimont \& Susan Fitzpatrick, 1972, p. 218-226) have demonstrated that people with higher levels of income focus their attention on the possibility to use money to ensure their own comfort and security. Obsession with money is more typical of people with lower level of income, they also tend to use money as a means to gain power over other people (Adrian Furnham, 1984, p. 501-509). 
Research of the monetary mindset of the American population has shown that people with high incomes tend to see interrelation between money and their achievements. That means that money for them is a sort of indicator of their own success. It is less typical of such people to see money as a root of all evil as compared to people with low levels of income. Thorough planning of their own budget and thrifty attitude to money is characteristic of people with lower incomes (Tomas Li-Ping Tang \& Pamela R. Gilbert, 1995, p. 327-332). However, James A. Roberts and Cesar J. Sepulveda M. (James A. Roberts and Cesar J. Sepulveda M., 1999, p. 19-35) have studied that people with higher income are more inclined to do financial planning. The authors explain it by the fact that Tang \& Gilbert, 1995 have studied people with lower levels of income. Michael Lynn (Adrian Furnham \& Michael Argyle, 1998, p. 332) has conducted cross-cultural study in 43 countries all over the world to study national differences in monetary mindsets. The majority of national groups have shown statistically different inverse correlation between the value people gave to money and their income. Thus, in more economically developed countries people consider money to be less important and, vice versa, the poorer the country is, the more concerned people are about the money (Adrian Furnham \& Michael Argyle, 1998, p. 332). However, Kent T. Yamauchi \& Donald I. Templer (Kent T. Yamauchi \& Donald I. Templer , 1982, p. 522-528) after doing the research on attitudes to money by representatives of different social groups have revealed that money attitudes practically do not depend on the level of income.

Studies on interrelations between money attitudes and level of education have shown that less educated people are more often financially obsessed and use money to as a tool to influence other people. More educated people very often become "discount hunters" (Adrian Furnham, 1984, p. 501-509). Also people with higher level of education pay more attention to planning their income, expenses and savings (James A. Roberts and Cesar J. Sepulveda, 1999, 19-35).

Thus, money attitudes of a person are closely interrelated not only with psychological variables but also with social and demographic ones. However, the character of this relation is affected by cultural and ethnic factors. Therefore, our research attempts to reveal social and demographic peculiarities of money attitudes of the Ukrainian youth

Research procedure. To determine money attitudes of a person, a Ukrainian variant of methodology by Tomas Li-Ping Tang called «Money Ethic Scale» (MAS) and a Ukrainian variant of the methodology by Adrian Furnham «Money Beliefs and Behaviour Scale» (MBBS) were used.

Social and demographic indicators included: gender, age, level of education, place of residence, level of income, employment and position.

Research participants were 246 people aged 20-35. Choice of this age period is explained by the highest professional and economic activity of people. Out of them 52,8 \% (130 people) are women and 47,2 \% (116 people) are men. While the research was conducted 44,3\% (109 people) of respondents were from 20 to 25 years old and 55,7 \% (137 people) - from 26 to 35 years old. This age division is conditioned by the fact that people under 25 graduate from educational 
institutions and start their professional activity, thus, are only becoming part of economic system, while older people are fully professionally and economically active. Division of those surveyed as to the level of education is the following: $15 \%$ (37 people) are people with vocational secondary education, 21,5\% (53 people) have basic higher education (Bachelor Degree), 63,5 \% (156 people) have complete higher education (Master or Specialist Degree). According to the place of residence respondents were divided as follows: 76,8 \% (189 people) live in big cities (oblast centres) and 23,2 \% (57 people) in small towns and villages (district centres, town-like settlements and villages). 53,3\% (131 people) are married, 43,5 $\%$ (107 people) are single and 3,2 \% (8 people) are divorced. According to the place of employment the group consists of: $46 \%$ (113 people) of those surveyed are employed in state organizations and enterprises, 39,4\% (97 people) work in commercial organizations, 7,3\% (18 people) are private entrepreneurs and 7,3\% (18 people) are unemployed. Out of them $81,6 \%$ (186 people) are subordinates and 18,4 \% (42 people) occupy senior positions. Level of income of respondents is: $48 \%$ (118 people) are those with low level of income that corresponds to less than 1 and 1-2 minimum wages (from less than 744 to $1488 \mathrm{hrn}$.); $30 \%$ (74 people) are respondents with average income which is within 2-5 minimum wages (from 1489 to $3720 \mathrm{hrn}$ ); $20 \%$ (51 people) are respondents with high level of income which constitutes from 5 and more minimum wages (from $3721 \mathrm{hrn}$.).

To process the results of the research methods of mathematical statistics were used aided by the programme STATISTICA Six Sigma, namely: correlation analysis, comparative analysis according to Student's t-criterion and unifactor dispersion analysis (variations analysis and Scheffe's test).

Findings of the research. Comparative analysis according to Student's t-criterion has shown statistically significant differences in men and women on scales «Money as a means of achieving and demonstrating success» $(\mathrm{p}=0.006)$ and «Power» $(p=0.002)$. Also correlation analysis has proved direct correlation between gender of the respondents and scales «Money as a means of achieving and demonstrating success» $(r=0.17$, with $\mathrm{p}<0.05)$ and «Power» $(\mathrm{r}=0.19$, with $\mathrm{p}<0.05)$ (Fig. $1)$. Thus, men show higher tendency of seeing money as a means of demonstrating their own success than women. For men money symbolizes success and in general becomes an indicator of their own successfulness in life. Also men are more inclined to use money as a means to influence other people and in this way to achieve their own success. They more often use money to boss around, harass and "buy" people by their own generosity.

The results of comparative and correlation analysis have indicated age differences in money attitudes in this group of respondents. Individuals aged 2025 more often see money as a means of attracting respect to a person $(p=0.02)$ as compared to people aged 26-35 (Fig. 2). Also revealed was inverse correlation between age and scale «Money as a means of attracting respect to a person» $(r=-$ 0.14 , with $\mathrm{p}<0.05$ ). That means that respondents of older age less often see money as a means to earn respect in society. Younger people more often see money as a good means to make more friends and attract respect among people. In their opinion, money helps better express their skills and competencies. 


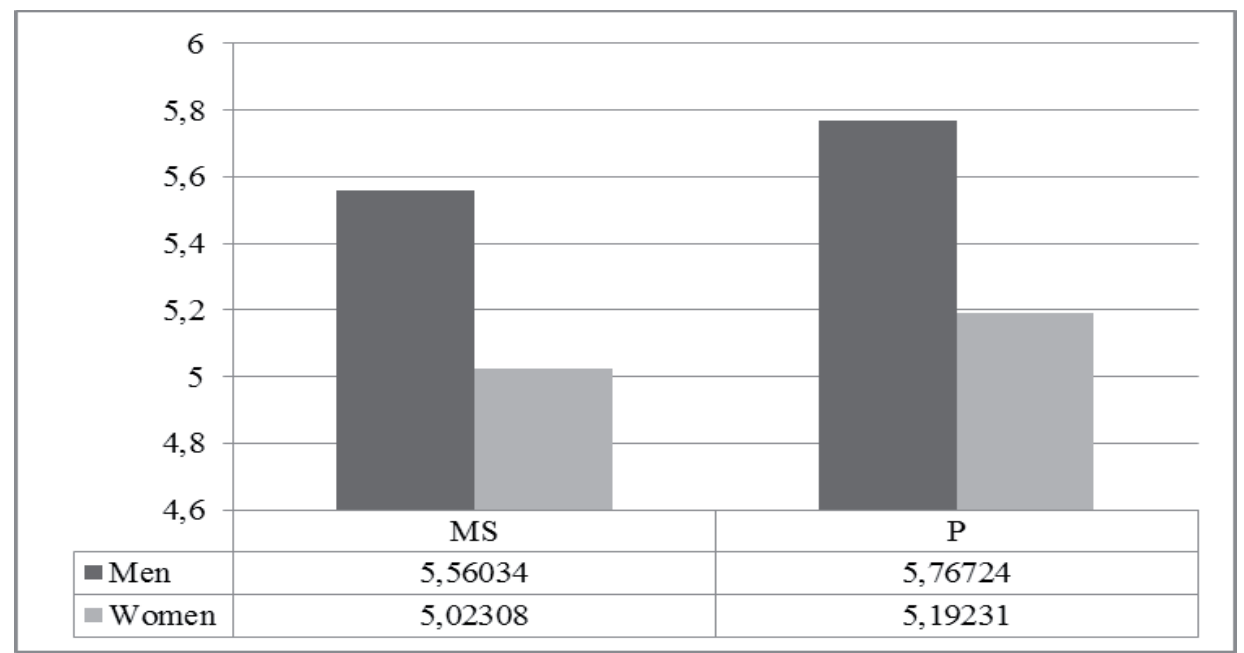

Figure 1. Statistically significant differences of money attitudes of men and women MS- «Money as a means of achieving and demonstrating success», P - «Power»

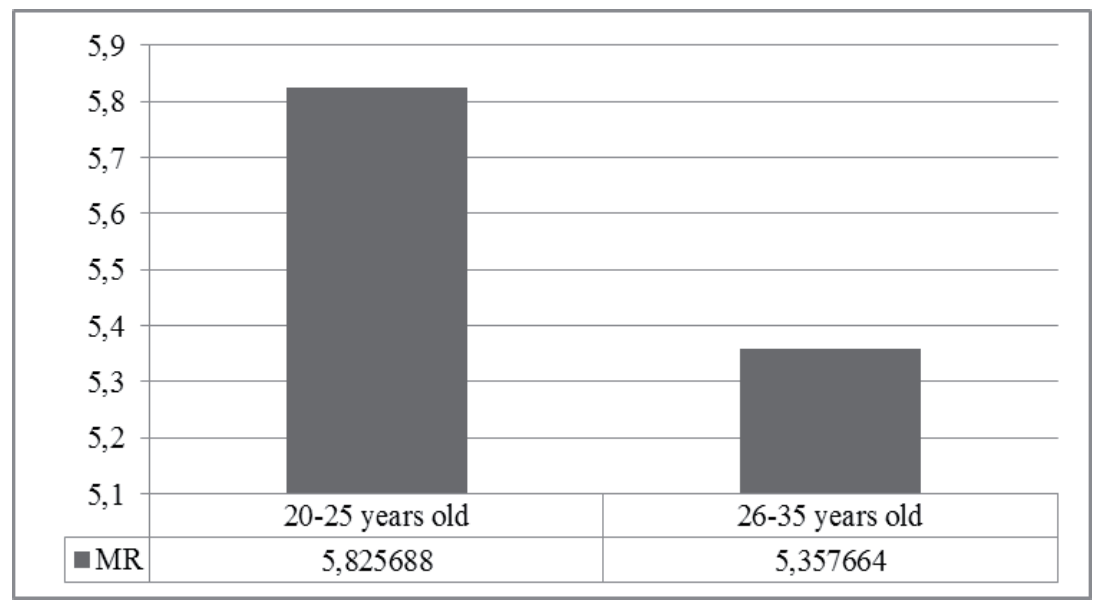

Figure 2. Statistically significant difference of monetary mindset in people of different age MR - «Money as a means of attracting respect to a person»

Application of unifactor dispersion analysis (variations analysis and Scheffe's test) allowed to reveal differences in indicators on the scales "Obsession with money» and «Inadequate handling of money» in people with different education levels. The group of respondents with vocational specialized education have shown higher level of obsession with money $(F=5.848, p=0.003, M=5.9730)$ than people with complete higher education $(\mathrm{F}=5.848, \mathrm{p}=0.003, \mathrm{M}=5.0833)$. They also have higher level of monetary mindset which testifies to inadequate handling 
of money $(\mathrm{F}=6.048, \mathrm{p}=0.003, \mathrm{M}=5.9459)$ as compared to those with complete higher education $(\mathrm{F}=6.048, \mathrm{p}=0.003, \mathrm{M}=5.0705)$. However, the group of people with basic higher education have not shown statistically significant differences as to the indicators on scales that reflect money attitudes (Fig 3).

Correlation analysis has proved interrelations between level of education and above-mentioned money attitudes for this group of those surveyed. Revealed was inverse correlation between education and scales «Obsession with money» $(r=-0.21$, with $p<0.05) i$ «Inadequate handling of money» $(r=-0.21$, with $p<0.05)$.

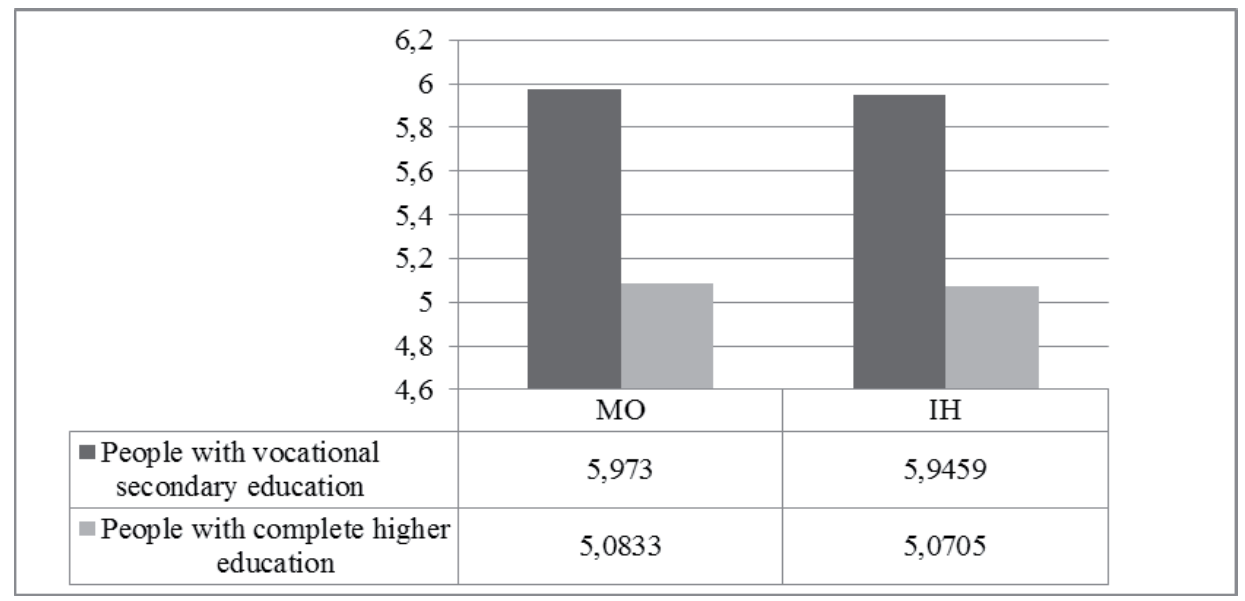

Figure 3. Statistically significant differences in indicators of money attitudes in people with different level of education $(\mathrm{p}<0.05)$

$\mathrm{MO}$ - «Obsession with money», IH - «Inadequate handling of money»

Thus, less educated respondents more often feel the need for money and are ready to use all legal actions to make more money. They more often are concerned about their financial condition and dream about what they can buy for money. They think that their income is lower than it should be at such a job. They more tend to think that money is the only thing one can rely on and money is the solution to all the problems. Also people with lower level of education are more characterized by purchases of unnecessary things only because these things are sold at reduced prices or are fashionable. It is more difficult for them to make decisions what to buy and they more often spend money on other people and are reluctant to spend it on themselves. They are more inclined to feel guilty when they spend money, however, they feel uncomfortable until they spend everything they have. They are of the opinion that they are bad at controlling their financial condition and feel that they are incapable of changing it.

Dependency between attitude to money and place of residence of the respondents was revealed by means of comparative analysis according to Student's t-criterion. It indicated statistically significant differences in indicators on the scales «Money as good», «Money as evil» and «Money as a means of achieving freedom and power» in people who live in big and small cities. Those sur- 
veyed who live in big cities show higher indicator on the scale «Money as good» $(p=0.03)$ and $«$ Money as a means of achieving freedom and power» $(p=0.03)$ as compared to people who live in towns and villages. However, the group of people who live in towns and villages is characterized by higher indicator on the scale «Money as evil» $(\mathrm{p}=0.02)$ than those residing in big cities (Fig. 4). The results of correlation analysis show inverse correlation between place of residence and scale «Money as good» $(\mathrm{r}=-0.15$, with $\mathrm{p}<0.05)$ and direct correlation with the scale «Money as evil» $(\mathrm{r}=0.14$, with $\mathrm{p}<0.05)$.

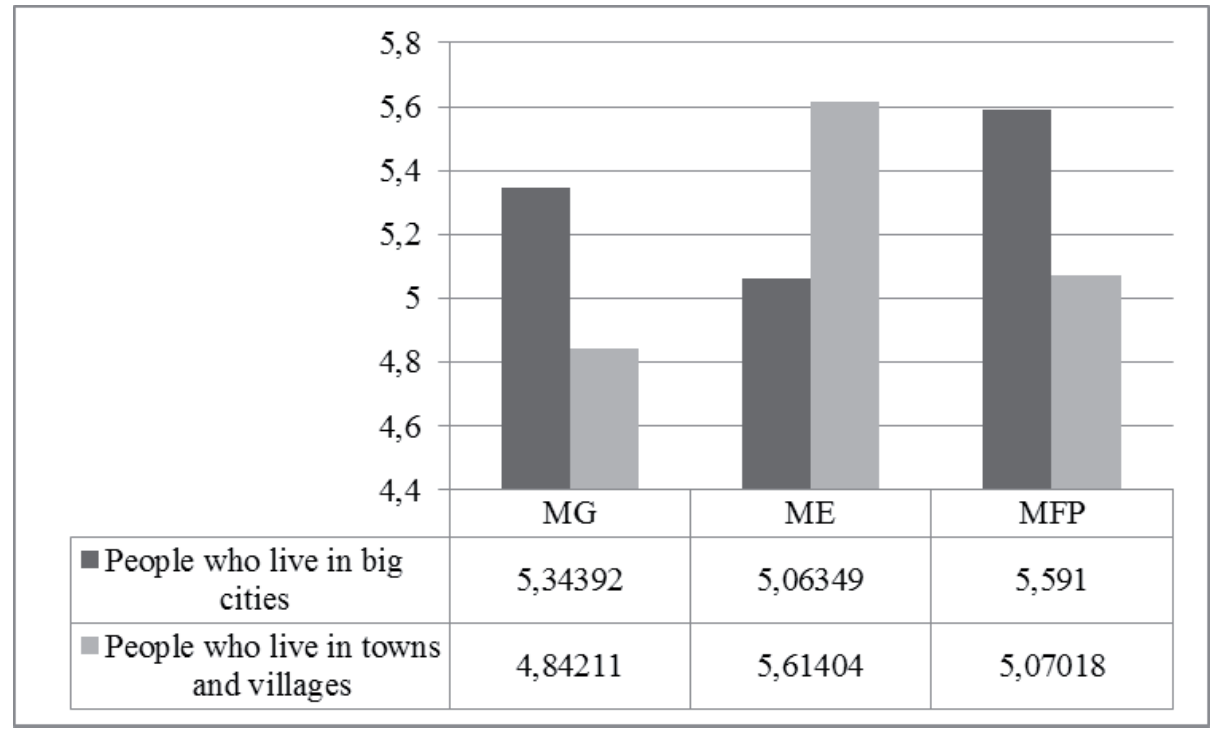

Figure 4. Statistically significant differences in indicators of money attitudes in people with different places of residence

MG - «Money as good», ME - «Money as evil», MFP - «Money as a means of achieving freedom and power»

Thus, the group of people that reside in big cities give to money more value and consider it to be an important factor in their life. In their opinion, money is something good that helps a person improve the quality of life, for instance, buy some luxury items. For such people money is more appealing and valuable than for people who live in small towns. In contrast, young people living in small towns more often show monetary mindset with negative emotional meaning and consider money to be a root of all evil. In their opinion, money is absolutely unnecessary and something to be ashamed of. It is more typical of them to feel some loss in case money is spent. Another peculiarity of people living in big cities is tendency to save money in bank accounts as, in their opinion, banks means reliability. They also think that money gives people a possibility to gain personal independence and power over other people.

According to the results of comparative analysis, there is a statistically significant difference between groups of people working in state and commercial institu- 
tions on the following scales of monetary mindsets: «Money as good» $(p=0.007)$, «Money as a means of achieving and demonstrating success» $(p=0.02)$, «Planning expenses» $(p=0.01)$ and «Inadequate handling of money» $(p=0.03)$ (Fig. 5). Some participants of the research who have their own business were not considered in this analysis as their part was 7,3\% from the general number of respondents. People who work in commercial institutions demonstrate higher indicators on scales «Money as good» and «Money as a means of achieving and demonstrating success" while people who work in state organizations have higher indicator on the scale «Planning expenses». Also present is direct correlation between place of employment and the scale «Money as good» $(r=0.15$, with $\mathrm{p}<0.05)$ and reversed relation with the scale «Money as evil» $(\mathrm{r}=-0.16$, with $\mathrm{p}<0.05)$.

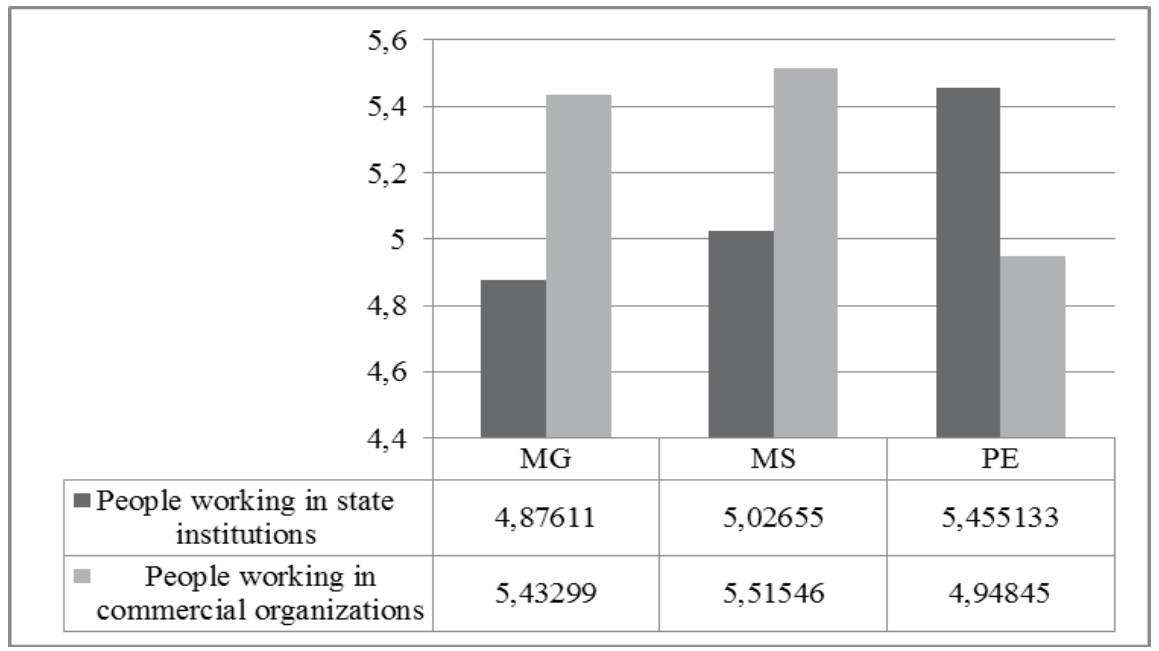

Figure 5. Statistically significant differences in indicators of money attitudes in people with different employment place

MG - «Money as good», MS - «Money as a means of achieving and demonstrating success», PE «Planning expenses»

Thus, young people working in commercial organizations tend to have totally positive attitude to money, giving to money high value. They are more inclined to consider money to be good and think that it is only beneficial for people. In their opinion, money symbolizes personal success and reflects their competence and achievements. People who work in state institutions are more meticulous about planning their budget, projecting all income and expenses, they try to pay all the bills on time to avoid financial punishment and generally are more prudent and careful about spending money. Taking into account the results of correlation analysis, we can assume that for civil servants money is emotionally more negatively coloured, symbolizes evil, something that brings people more evil that good.

Comparing groups of people in senior and subordinate positions we managed to show the in emotional attitude to money difference. People in senior positions are characterized by higher indicator on the scale «Money as good» $(p=0.006)$ while sub- 
ordinates - by higher indicator on the scale «Money as evil» $(p=0.02)$. Thus, bosses have more positive attitude to money and give money more value. People who are not in the position of authority are more inclined to have negative attitude to money.

Comparative analysis according to Student's t-criterion made it possible to indicate statistically significant differences in money attitudes of people with different levels of income. To make groups equal, the groups of respondents with average and high level of were united into one as about half of the general group $(48 \%)$ are people with low level of income. The results show statistically significant difference on scales «Money as good» $(p=0.01)$, «Money as evil» $(p=0.000)$, «Power» $(p=0.000)$ and «Inadequate handling of money» $(p=0.01)$. Respondents with average and high level of income have got higher indicators on such money attitudes as «Money as good» and «Power» and people with low income - «Money as evil» and «Inadequate handling of money». There is direct correlation between income and scales «Money as good» $(\mathrm{r}=0.17$, with $\mathrm{p}<0.05)$ and «Power» $(\mathrm{r}=0.19$, with $\mathrm{p}<0.05)$; inverse correlation is found between income and scales «Money as evil» $(\mathrm{r}=-0.25$, with $\mathrm{p}<0.05)$ and «Inadequate handling of money» $(\mathrm{r}=-0.14$, with $\mathrm{p}<0.05)$.

Thus we can state that the higher the income of a person, the more valuable money is for this person. People with average and high level of income more often consider money to be a taken for influence and as a means to get power over other people. In contrast, people with low wages have more negative attitudes to money, they think that money is more evil than good and have weak control over their financial condition.

Conclusions. The result of the research of money attitudes of the Ukrainian youth have shown that there is dependency between attitude to money and such social and demographic characteristics as gender, age, level of education, place of employment, position and level of income. Positive attitude to money for this group of respondents is characteristic of people who live in big cities, work in commercial organizations and occupy senior positions and have average and high levels of income. In contrast, people who live in small towns and villages, occupy subordinate positions and have low income show negative attitudes to money. As place of residence, employment and position to a great extent determine level of income of a person, it is possible to conclude that financially «happy» people consider money to be good and of more value than people with lower income.

Men and people who work in commercial institutions more often tend to see money as a means of achieving and demonstrating their own success. For them money is a symbol of their own success and reflects and demonstrates their achievements. Also men more often than women use money as a tool to influence other people. The relationship between the amount of money and respect is traced in young respondents.

Less educated people are more concerned about their financial condition; they often dream of what they can buy for money and constantly feel the need for money. Also they tend to experience feelings of guilt for spending money, buying unnecessary things and have worse control over their finances as compared to people with better education. 


\section{REFERENCES}

Furnham Adrian \& Argyle Michael (1998), The psychology of money. New York: Routledge.

Furnham Adrian (1984), Many sides to the coin: the psychology of money usage, "Personality and Individual Differences" 5 (5).

Hanley Alice \& Wilhelm Mari S. (1992), Compulsive buying: An exploration into self-esteem and money attitudes, "Journal of Economic Psychology" 13.

Lim Vivien K. G. \& Teo Thompson S. H. (1997), Sex, money and financial hardship: an empirical study of attitudes towards money among undergraduates in Singapore, "Journal of Economic Psychology" 18.

Mialenko Viktoriya (2008), Socio-psychological mechanisms of financial behavior of young people: Abstract of PhD thesis in Psychology: 19.00.05/ Institute of Social and Political Psychology affiliated to the Academy of Pedagogical Sciences of Ukraine.

Moskalenko Valentyna (2004), Current research directions in economic psychology, "Social Psychology" 3 (5).

Prince Melvin (1991), Gender and money attitude of young adults, "Proceedings of the Conference on Gender and Consumer Behavior".

Roberts James A. and Sepulveda Cesar J. (1999), Demographics and money attitudes: a test of Yamauchi \& Templer's (1982) money attitude scale in Mexico, "Personality and Individual Differences" 27.

Tang Tomas Li-Ping \& Gilbert Pamela R. (1995), Attitude toward money as related to intrinsic and extrinsic job satisfaction, stress and work-related attitudes, "Personality and Individual Differences" 19 (3).

Wernimont Paul F. \& Fitzpatrick Susan (1972), The meaning of money, "Journal of Applied Psychology" 56.

Yamauchi Kent T. \& Templer Donald I. (1982), The development of a money attitudes scale, "Journal of Personality Assessment" 46.

Zubiashvili Iryna (2009), Attitude to Money as a Factor of Economic Socialization of High School Students: Abstract of PhD thesis in Psychology: 19.00.05/ Institute of Psychology named after G.S. Kostiuk affiliated to the Academy of Pedagogical Sciences of Ukraine. 